Institute of $\mathbf{F}_{\text {ood and }} \mathbf{A}$ gricultural $\mathbf{S}_{\text {ciences }}$

\title{
Florida Solid and Hazardous Waste Regulation Handbook: Emergency Planning and Community Right-to-Know Act (EPCRA) 1
}

Michael T. Olexa, Aaron Leviten, and Kelly Samek²

\section{What Is the Emergency Planning and Community Right-to-Know Act (EPCRA)?}

The Emergency Planning and Community Right-to-Know Act (EPCRA) was passed in 1986 to improve emergency response to accidental releases of toxic and/or hazardous chemicals into the environment. EPCRA primarily serves a planning purpose. It required governors to set up State Emergency Response Commissions (SERCs). Those commissions then set up Local Emergency Planning Committees (LEPCs).

\section{How Does EPCRA Work?}

The structure can be summarized as follows:

- EPA oversees the State Emergency Response Commissions (SERCs).

- State commissions oversee the Local Emergency Planning Committees (LEPCs).
- LEPCs oversee local emergency planning districts.

\section{What Do Local Emergency Planning Committees Do?}

LEPCs are responsible for developing an emergency response plan, reviewing it once or more annually, and providing citizens with information about chemicals in the community. The emergency response plan must identify the location of facilities within their district that use hazardous substances and the types of substances used by those facilities. The plan must also describe procedures for immediate response to a chemical accident.

\section{What Substances Are Regulated by EPCRA?}

EPA has established a comprehensive list of extremely hazardous substances. EPCRA Section 302 regulates 356 extremely hazardous substances; Section 304 regulates more than 1000 substances;

1. This is EDIS document FE448, a publication of the Department of Food and Resource Economics, Florida Cooperative Extension Service, UF/IFAS, University of Florida, Gainesville, FL. Published December 2003. Please visit the EDIS website at http://edis.ifas.ufl.edu.

2. Michael T. Olexa, Professor in the Department of Food and Resource Economics and Director of the Agricultural Law Center, Florida Cooperative Extension Service, UF/IFAS, University of Florida, Gainesville, FL, and Member of the Florida Bar and Chair of the Agricultural Law Committee of the Florida Bar; Aaron Leviten, Attorney in Orlando and guest lecturer on pesticide litigation at the University of Florida; and Kelly Samek, 2003 graduate of the Levin College of Law at the University of Florida.

The Institute of Food and Agricultural Sciences is an equal opportunity/affirmative action employer authorized to provide research, educational information and other services only to individuals and institutions that function without regard to race, color, sex, age, handicap, or national origin. For information on obtaining other extension publications, contact your county Cooperative Extension Service office. Florida Cooperative Extension Service/Institute of Food and Agricultural Sciences/University of Florida/Christine Taylor Waddill, Dean. 
Sections 311 and 312 regulate 500,000 products; and Section 313 regulates 650 chemicals and categories.

Because of the many substances regulated and the different standards involved, you should contact EPA or your Local Emergency Planning Committee for more information about the standards and the reporting requirements.

\section{What Substances Are Exempt from EPCRA?}

Substances that are specifically exempt from EPCRA include:

- any food, or food additive, drug or cosmetic regulated by the Food and Drug

Administration.

- any substance used for household purposes.

- any substance that is present in the same form and concentration as a product packaged for use by the general public.

- any substance used in a research laboratory by a technically qualified individual,

- any substance used in routine agricultural operations.

- any substance that is a fertilizer held for sale by a retailer to an ultimate customer.

- any substance present as a solid in any manufactured item so long as exposure to the substance does not occur under normal conditions of use.

If you do not meet any of these exemptions, you should contact your local emergency planning commission for more information about the regulations and requirements you must follow.

Although routine agricultural operations are exempt from EPCRA, state law may regulate agricultural chemicals and their uses more strictly. You should contact the Department of Agriculture and Consumer Services (DACS) and the Department of Community Affairs (DCA) for more information on state right-to-know laws and agricultural worker safety programs.

\section{What Is a Material Safety Data Sheet (MSDS) and Inventory Reporting?}

Under Occupational Safety and Health Administration (OSHA) regulations, employers are required to maintain a Material Safety Data Sheet (MSDS) for any hazardous chemicals stored or used in the workplace.

If a facility is required to prepare or have available a material safety data sheet (MSDS) for a hazardous chemical under OSHA and its regulations, the facility must also report to:

- the Local Emergency Planning Committee.

- the State Emergency Response Commission.

- the fire department having jurisdiction over the facility.

The required reports include both of the following:

- a hazardous chemical inventory report.

- a material safety data report.

These reports must be made:

- for 10,000 pounds or more of each hazardous chemical present at one time.

- for a chemical designated by EPCRA as an "extremely hazardous chemical" in an amount equal to or greater than 500 pounds, or the EPCRA designated "threshold planning quantity," whichever is lower.

Information from these reports will be made available to the general public.

\section{Acknowledgments}

The authors are indebted to the personnel of both state and federal agencies who gave their time and advice in the preparation of this handbook. The authors are also indebted to the following University of Florida personnel for a review and critique of the first draft of this publication: Dr. Thomas Dean, Pesticide Education Specialist, and Dr. Norman Nesheim, Pesticide Information Coordinator. Special 
recognition is also due to Mr. Richard Budell of the

Office of Agricultural Water Policy of the Florida

Department of Agriculture and Consumer Services

for providing funds for the development of this

handbook.

This handbook is designed to provide an accurate, current, and authoritative summary of the principal Florida laws that directly or indirectly relate to agriculture. It should provide a basic overview of the many rights and responsibilities farmers and farmland owners have under Florida laws. The reader is provided information about these rights and responsibilities and the appropriate contacts for more detailed information. However, the reader should be aware that because the laws, administrative rulings, and court decisions on which this publication is based are subject to constant revision, portions of this publication could become outdated at any time. Many details of cited laws are also left out due to space limitations.

This handbook is distributed with the understanding that the authors are not engaged in rendering legal or other professional advice and the information contained herein should not be regarded or relied upon as a substitute for professional advice. It is not all-inclusive in providing information to achieve compliance with laws and regulations governing the practice of agriculture. For these reasons, the use of these materials by any person constitutes an agreement to hold harmless the authors, UF/IFAS, the Agricultural Law Center, and the University of Florida for any liability claims, damages, or expenses that may be incurred by any person as a result of reference to or reliance upon the information contained in this publication. 